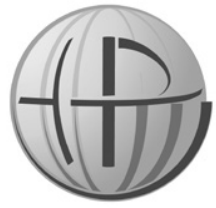

Horyzonty Polityki 2020, Vol. 11, No 34

\section{LeSZeK NowaK}

http://orcid.org/0000-0002-7022-5817

Uniwersytet Warszawski

Wydział Nauk Politycznych i Studiów Międzynarodowych e-mail: 1.nowak2@uw.edu.pl

DOI: $10.35765 /$ HP.1870

\title{
Demokracja i mizantropia. Przemiany wyobrażeń na temat ludu a problem intelektualnego uprawomocnienia demokracji
}

\section{Streszczenie}

CEL NAUKOWY: Celem tego artykułu jest analiza związku między wyobrażeniami z zakresu antropologii filozoficznej a problemem intelektualnej prawomocności demokracji.

PROBLEM I METODY BADAWCZE: W artykule próbuję odpowiedzieć na pytanie, jaki jest związek między poglądami na temat natury ludzkiej a stosunkiem do demokracji. Analizuje ten problem interpretując klasyczne dzieła z zakresu myśli politycznej.

PROCES WYWODU: Punktem wyjścia jest konstatacja: niechęć wobec demokracji wyrastała w dużej mierze z mizantropii. Demokracja nie była uznawana za ustrój godny poparcia, ponieważ nie wierzono w racjonalność zwykłego człowieka i jego zdolność do odpowiedzialnego uczestnictwa w życiu publicznym. Ta sytuacja zmienia się w epoce Oświecenia, kiedy to podważono pesymizm antropologiczny i sformułowane zostały teorie stanowiące podstawę dla idei intelektualnej prawomocności demokracji. Późniejszy bieg wypadków w dużym stopniu te teorie zakwestionował, ale mimo to demokracja na Zachodzie uznawana jest za jedyną prawomocną formę rządu.

WYNIKI ANALIZY NAUKOWEJ: Analiza prowadzi do sformułowania poglądu o paradoksalnym charakterze współczesnej demokracji. Z jednej strony, istnieje konsensus co do intelektualnej prawomocności demokracji, z drugiej - w teorii i praktyce powszechnie kwestionowana jest zdolność zwykłego człowieka do rozumnego uczestnictwa w życiu publicznym. 
WNIOSKI, INNOWACJE, REKOMENDACJE: Wyniki analizy powinny skłonić politologa do zmiany sposobu rozumienia charakteru współczesnej demokracji. Ustrój ten nosi nazwę demokracja, ale wydaje się mieć coraz mniej wspólnego z nadziejami tych autorów, którzy sformułowali jej intelektualne założenia.

\title{
SŁOWA KLUCzOWE:
}

Oświecenie, demokracja, mizantropia, natura ludzka

\author{
Abstract \\ DEMOCRACY AND MISANTHROPY. \\ CHANGES IN PERCEPTIONS OF THE PEOPLE \\ AND THE PROBLEM OF INTELLECTUAL LEGITIMACY \\ OF DEMOCRACY
}

RESEARCH OBJECTIVE: The purpose of this article is to analyse the relationship between ideas of philosophical anthropology and the problem of intellectual legitimacy of democracy.

THE RESEARCH PROBLEM AND METHODS: In the article I am trying to answer the question, what is the relationship between views on human nature and attitude to democracy. I analyse this problem by interpreting classic works of political thought.

THE PROCESS OF ARGUMENTATION: The starting point is the statement: aversion to democracy arose largely from misanthropy. Democracy was not considered as intellectually legitimate regime, because it was not believed in the rationality of an ordinary person and his ability to participate responsibly in public life. This situation changes during the Enlightenment, when anthropological pessimism was undermined, and the theories underlying the idea of the intellectual legitimacy of democracy were formulated. The later course of events largely questioned these theories, but nevertheless democracy in the West is considered as the only legitimate form of government.

RESEARCH RESULTS: This leads me to a view on the paradoxical nature of modern democracy. On the one hand, there is a consensus regarding the intellectual legitimacy of democracy. On the other hand, in theory and practice, the ability of ordinary people to participate reasonably in public life is commonly questioned.

CONCLUSIONS, INNOVATIONS AND RECOMMENDATIONS: The results of the analysis should prompt the political scientist to change the way of understanding the nature of modern democracy. This system is called 
democracy, but it seems to have less and less to do with the hopes of those authors who formulated its intellectual assumptions.

\section{KeYwORDS:}

enlightenment, democracy, misanthropy, human nature

Dziejom demokracji towarzyszyły przemiany wyobrażeń z zakresu antropologii filozoficznej. Niektóre z nich przyczyniały się do intelektualnego uprawomocnienia demokracji, inne ją podważały. Jest rzeczą interesująca, że ustrój, który obecnie często traktujemy jako jedyną prawomocną formę rządu, przez stulecia cieszył się złą sławą. W dziejach myśli politycznej aż do XIX wieku dominowało przeświadczenie, że lud nie posiada intelektualnych i moralnych kwalifikacji do rządzenia. Na taki pogląd wpłynął m.in. klasyczny racjonalizm, który pozostawił nam obraz demosu jako tłumu kierującego się namiętnościami, czy chrześcijański pesymizm antropologiczny. Platon w VI księdze Państwa porównał lud do bestii. Według antropologii św. Augustyna grzech pierworodny skaził naturę ludzką. Jego istotą jest ludzka pycha - wyobrażenie siebie w innym miejscu niż to, które nam zostało dane przez Boga. Skażenie ludzkiej natury oznacza zepsucie ludzkiej woli - wpływa to nie tylko na nasze czyny, ale także na nasze pragnienia i intencje. Jeśli większość ludzi kieruje się skażoną wolą i nie potrafi uczynić rozumu swoim przewodnikiem, to trudno uznać pomysł, aby lud rządził sam sobą za rozumny.

\section{OPTYMIZM ANTROPOLOGICZNY OŚWIECENIA}

Na zmianę reputacji demokracji wpłynęły różne czynniki. Jednym z nich była przemiana wyobrażeń na temat natury ludzkiej w czasach Oświecenia. Program tej epoki można najłatwiej streścić odwołując się do słynnej definicji Immanuela Kanta. Na pytanie sformułowane w tytule głośnego artykułu Co to jest Oświecenie?, filozof odpowiadał, że jest to „wyjście ze stanu niepełnoletniości” (Kant, 2012). Osiągnięcie pełnoletności oznaczało wyzwolenie rozumu spod obcego kierownictwa. Emancypacja rozumu była z kolei koniecznym warunkiem wzięcia odpowiedzialności za własne życie - zarówno w wymiarze 
indywidualnym, jak i zbiorowym. Człowiek, który staje się racjonalnym i odpowiedzialnym podmiotem moralnym, to istota dojrzała. Człowiek taki, zdolny do pokierowania własnym losem, to aktor bez którego trudno sobie wyobrazić dobrze działającą demokrację. Zaznaczmy jedną rzecz - samo słowo demokracja w wieku XVIII było jeszcze obarczone negatywnymi skojarzeniami. Ale to właśnie u autorów Oświecenia można znaleźć przewartościowania intelektualne, które samą koncepcję demokracji czyniły czymś prawomocnym.

Ernst Cassirer pisał w książce o Oświeceniu, że mimo wielu różnic filozofów tamtej epoki łączyło odrzucenie koncepcji grzechu pierworodnego (Cassirer, 2010, s. 130). Nie należy z tego wyprowadzać zbyt pochopnego wniosku, że wszyscy myśliciele Oświecenia byli naiwnymi optymistami antropologicznymi. Wspomniany wcześniej Immanuel Kant napisał artykuł pod wymownym tytułem O obecności złego pierwiastka obok dobrego, czyli zło radykalne w naturze ludzkiej. Amerykańscy Ojcowie Założyciele zauważyli, że samo istnienie państwa jest odpowiedzią na niedostatki natury ludzkiej. James Madison, uzasadniając podział władz i ich wzajemną kontrolę, pisał:

Ale czyż same władze nie są najwierniejszym odbiciem natury ludzkiej? Gdyby ludzie byli aniołami, żadne władze nie byłyby potrzebne (Madison, 1999, s. 151).

Filozofowie uważali, że nawet jeśli człowiek nie jest z natury dobry, to nie jest też zły, a w każdym razie można go kształtować, uczynić istotą bardziej racjonalną. Jak to można zrobić? W tej sprawie nie było jednomyślności, ale warto zwrócić uwagę na kilka pomysłów, które wtedy zostały przedstawione.

Najbardziej naiwny pomysł sformułowali materialiści. Julien Offray de La Mettrie, autor osławionej książki Człowiek - maszyna, uważał, że „materializm jest odtrutką na mizantropię" (Hazard, 1972, s. 122) Zdaniem materialistów błąd polegał na tym, że przyjęto fałszywe założenie o złej naturze ludzkiej. Wychowanie człowieka, prawa i instytucje zaprojektowano dla tak wyobrażonej istoty.

Stąd - pisze Paul Hazard - zgryźliwa moralność, która dążyła do tego tylko, aby go uciskać. Należy, przeciwnie, wspomagać instynkt, który każe nam dążyć do szczęścia, i rozum, który dostarcza nam środków pozwalających je osiągnąć (Hazard, 1972, s. 155). 
To instytucje zdeprawowały człowieka. Jest taki, a nie inny, nie dlatego, że tak go stworzyła natura, lecz dlatego, że tak zdeformowała go organizacja życia społecznego. Brak samodzielności człowieka również jest rezultatem zaplanowanej deprawacji. Jak pisał Paul Holbach:

wychowując człowieka w lęku przed niewidzialnymi tyranami, uczyniła go także służalczym i tchórzliwym wobec władców ziemskich oraz zdusiła w nim wszelką umiejętność samodzielnego kierowanie swym losem (Cassirer, 2010, s. 123).

Człowiek dla materialistów jest istotą plastyczną. Różnice między ludźmi są konsekwencją różnic warunków. Skoro tak właśnie jest, to zmiana warunków wychowania zminimalizuje różnice. Człowiek byłby zdolny do trafnego osądu, gdyby nie ignorancja i namiętności, będące skutkiem złej edukacji.

Optymizm antropologiczny widoczny jest także w różnych koncepcjach etycznych. Filozofowie Oświecenia wierzyli, że jednostka ludzka, wyemancypowana spod władzy tradycji i religii, będzie zdolna do właściwego pokierowania własnym życiem. Takie pojęcia, jak zmysł moralny, sympatia czy oddźwięk uczuciowy wyrażały wiarę, że człowiek bez obcego kierownictwa potrafi kierować się ku dobru. Dla zilustrowania tego problemu odwołajmy się do przemyśleń przedstawicieli szkockiego Oświecenia, nurtu, który w porównaniu z materialistami wyróżniał się realizmem i trzeźwością osądu.

Ważnym pojęciem, do którego odwoływali się szkoccy filozofowie moralności, był „zmysł moralny”. Anthony Shaftesbury - bodaj najbardziej optymistyczny z tego grona - uważał po prostu, że jest on zakorzeniony w ludzkim sercu; inni sądzili, że w „ludzkiej wrażliwości w formie współczucia" (Himmelfarb, 2018, s. 48-49). W każdym razie wynikało z tego, że odczuwanie współczucia jest naturalnym uczuciem; to raczej człowiek, który tego uczucia nie doświadcza, odbiega od natury.

Adam Smith sformułował pogląd, że w wyniku ,oddźwięku uczuciowego" stawiamy się w sytuacji naszego bliźniego.

Jakkolwiek samolubny miałby być człowiek - pisał - są niewątpliwie w jego naturze jakieś pierwiastki, które powoduja że interesuje się losem innych ludzi i sprawiaja, że ich szczęście jest dla niego nieodzowne, choć jedyna przyjemność jaką może stąd czerpać, to przyjemność 
obserwowania. Tego właśnie rodzaju jest współczucie (pity), litość (compassion) - uczucie którego doznajemy wobec nieszczęścia innych wtedy, gdy jesteśmy jego świadkami, czy też gdy udało się nam żywo je sobie uświadomić (...) [To za] sprawą wyobraźni stawiamy się w jego sytuacji (Smith, 1989, s. 62).

Trudno tak sformułowany pogląd pogodzić ze stanowiskiem, że człowiek ma złą wolę, która czyni go nieprzyjacielem bliźnich.

Mimo że szkoccy filozofowie moralności nie wypowiadali otwarcie pochwał dla demokracji, a nawet niektórzy ją krytykowali, to jednocześnie wyrażali przeświadczenie o równości między ludźmi. Nawet konserwatysta Dawid Hume przychylał się do takiej oceny

Wszyscy ludzie - pisał - są sobie niemal równi pod względem siły fizycznej, a nawet zdolności i władz umysłowych, dopóki nie zaczną pielęgnować ich w drodze edukacji (Himmelfarb, 2018, s. 105).

Gertrude Himmelfarb, wybitna znawczyni tematu, podsumowuje to w sposób następujący:

Demokratyzm szkockich filozofów moralności był znacznie bardziej autentyczny niż francuskich philosophes. Ci ostatni, mimo deklarowanego radykalizmu swoich poglądów politycznych, pozostali bardzo „arystokratyczni” w myśleniu o możliwościach tzw. zwykłego człowieka" (Himmelfarb, 2018, s. 106).

Najbardziej spektakularnym wyrazem optymizmu antropologicznego jest oświeceniowa teoria postępu. Wiara w postęp była w Oświeceniu dominującym nurtem $w$ refleksji nad historią. Niektórzy wierzyli w możliwość postępu, inni mieli co do tego pewność, która przybrała formę teoretyczną. Jedną z najbardziej znanych była teoria, którą wyłożył Antoine de Condorcet w Szkicu obrazu postępu ducha ludzkiego poprzez dzieje. Warto jej poświęcić chwilę uwagi, ponieważ rozwija jeden z motywów charakterystycznych dla Wieku Światełprzeświadczenie, że postęp wiedzy jest pozytywnie skorelowany z przemianami w dziedzinie moralności i polityki. „Natura skuła nierozerwalnym łańcuchem prawdę, szczęście i cnotę" (Condorcet, 1957, s. 236).

Postęp w dziedzinie wiedzy pozytywnie wpływa na przemiany w dziedzinie polityki. Condorcet, który był aktywnym uczestnikiem 
rewolucji francuskiej, uważał, że to właśnie w jego czasach Francuzi i Angloamerykanie wskazują kierunek „obalenia nierówności między narodami, większą równość w obrębie tego samego ludu i rzeczywiste udoskonalenie się człowieka" (Condorcet, 1957, s. 212-213).

Mimo że Condorcet zginął w czasie terroru rewolucyjnego, sądził, że przemiany, jakie rewolucja wniosła do dziejów ludzkości, mają charakter epokowy. W jego wywodzie uderza wiara w siłę intelektualnych zasad, które mają nieodparty charakter:

Jeśli przyjrzymy się współczesnemu światu - pisał - stwierdzimy przede wszystkim, że zasady konstytucji francuskiej stały się w Europie zasadami wszystkich ludzi światłych (Condorcet, 1957, s. 214).

Triumf światłości nad ciemnością jest zatem nieuchronny. Retoryka Condorceta razi dzisiaj pretensjonalnością i naiwnością. Jest ona jednak jaskrawym wyrazem przeświadczenia, które zyskało wielką popularność w kulturze europejskiej - rozwój nauki oraz edukacji ma niezaprzeczalnie dobroczynny wpływ na kondycję moralną ludzkości.

Oczywiście nie tylko rozwój wiedzy był postrzegany jako źródło postępu. Warto zasygnalizować, że według niektórych przedstawicieli Oświecenia taką rolę miał spełniać także wolny handel sprzyjający porozumieniu między narodami, łagodzący obyczaje i eliminujący ubóstwo.

Nadzieje wiązano także z debatą publiczną. To rządy despotyczne opierały się na niewiedzy. Dzięki debacie publicznej możliwe stało się napiętnowanie opinii wyrastających z przesądów. Z drugiej strony, dzięki debacie w sferze publicznej mogły pojawić się poglądy, które wcześniej cenzurowano, a ich zwolenników prześladowano (Filipowicz, 2007). Argumentację tę rozwinął w XIX wieku John Stuart Mill w klasycznym eseju $O$ wolności.

Jan Jakub Rousseau, mimo że należy do najważniejszych przedstawicieli Oświecenia, właściwie nie zgadzał się ze wszystkimi przywołanymi wyżej autorami. Do materialistów odnosił się z wrogością. Uważał, że są wulgarnymi symplifikatorami, którzy nie zrozumieli ludzkiej kondycji. W odróżnieniu od szkockich filozofów moralności, którzy sądzili, że oddziaływanie społeczeństwa na jednostkę jest dla niej korzystne, Rousseau właśnie w społeczeństwie widział źródło deformacji człowieka. Jego błyskotliwa kariera rozpoczęła się od 
Rozprawy o naukach i sztukach, w której odrzuca tezę, zgodnie z którą postęp w dziedzinie wiedzy przyczynia się do postępu moralności. Nie podzielał także optymistycznych założeń dotyczących pozytywnych skutków wolności słowa. Łączy go jednak z nimi przeświadczenie, że człowiek jest istotą elastyczna, podatną na zmiany. Rousseau używa pojęcia natura ludzka, ale uważa, że jest ona zmienna.

W popularnych wyobrażeniach to przede wszystkim Rousseau przedstawiany jest jako niepoprawny optymista, który głosił ideę powrotu człowieka do natury. Odrzucał dogmat o grzechu pierworodnym, co nie oznacza, że przyjmował naiwnie optymistyczny pogląd na naturę ludzką. Człowieka naturalnego wprawdzie cechuje naturalna dobroć, ale rozwój cywilizacji go zdeformował. Obraz deprawacji ludzkiej, odmalowany przez Rousseau w Rozprawie o pochodzeniu nierówności, jest niezwykle sugestywny, a porównanie poczynione przez Cassirera do Pascala ani trochę nie wydaje się przesadne. Rousseau jednak, w odróżnieniu od autora Myśli, wierzył w możliwość odrodzenia człowieka. Pisał, że nie można ustalić granic natury ludzkiej tam, gdzie je widzą ludzie zdeformowani przez złe obyczaje i instytucje:

Granice możliwości w dziedzinie moralnej-pisał - nie są tak ciasne, jak sądzimy; ścieśniają je nasze ułomności, nasze wady, nasze przesądy. Dusze przyziemne nie wierzą wcale w wielkich ludzi; nędzni niewolnicy uśmiechają się drwiąco na dźwięk wyrazu „wolność" (Rousseau, 2010, s. 93).

Czy możliwa jest regeneracja w przypadku gatunku ludzkiego jako takiego? W tej sprawie Rousseau był raczej sceptyczny:

Istnieje u narodów, podobnie jak u ludzi, okres młodości lub też dojrzałości, na który trzeba poczekać, zanim go poddamy ustawom; ale dojrzałość ludu nie zawsze łatwo poznać; a jeżeli działania ją uprzedzą dzieło będzie chybione. Jeden lud można wdrożyć do karności w chwili narodzin, inny nie będzie zdyscyplinowany po dziesięciu wiekach (Rousseau, 2010, s. 50).

Mimo tego sceptycyzmu wielu czytelników właśnie u niego odnalazło wiarę w możliwość takiej regeneracji. Jak wiadomo w czasie rewolucji francuskiej poglądy Rousseau cieszyły się popularnością (Furet, 1997). 
Przemiana ludzkiej kondycji mogła się dokonać nie poprzez powrót do stanu natury - to było niemożliwe - lecz poprzez radykalne uwspólnotowienie człowieka. W Umowie społecznej Rousseau przedstawił wizję wielkiego prawodawcy, który tworzy instytucje, w obrębie których następuje przemiana ludzkiej natury:

Ten, kto podejmuje się stworzyć lud - pisał - powinien czuć się na siłach zmienić, że tak powiem, naturę ludzką; przekształcić każdą jednostkę, stanowiącą samą przez się całość doskonałą i samoistna, w część większej całości, od której owa jednostka otrzymuje niejako życie i byt; zmienić ustrój człowieka, aby go wzmocnić; zastąpić istnienie fizyczne i niezależne, otrzymane przez nas wszystkich od natury, bytem częściowym i moralnym (Rousseau, 2010, s. 46).

Kluczowym aspektem dziedzictwa Rousseau jest przeświadczenie, że za pomocą praw można podjąć się zadania regeneracji ludzkiej istoty. „Nie ulega wątpliwości - pisał - że ludy stają się w końcu tym, co z nich zrobi rząd" (Rousseau, 1956, s. 299). Próbując skonkretyzować charakter jego zamysłu, należy zwrócić uwagę na patriotyzm, czy też - jeśli posłużymy się tym terminem w sposób neutralny aksjologicznie - na nacjonalizm jako sposób uszlachetnienia natury ludzkiej (Plattner, 1997). Jego argumentacja jest godna uwagi:

Zdaje się, że życzliwość dla ludzi - pisał - rozwiewa się i słabnie, w miarę jak się rozszerza na całą ziemię, i że nie zdołalibyśmy tak się wzruszyć jakimiś klęskami Tartarii czy Japonii, jak wzrusza nas klęska któregokolwiek z narodów europejskich. Zainteresowanie i współczucie musimy ograniczyć niejako i skupić, żeby mu nadać żywotność. (...) Największych z pewnością cudów w dziedzinie cnoty dokonała miłość ojczyzny: to uczucie pełne słodyczy a życie, łączące potęgę miłości własnej z całym pięknym cnoty, nadaje tej ostatniej energię (...) czyni z niej najbardziej bohaterską ze wszystkich namiętności (Rousseau, 1956, s. 304).

Tak więc patriotyzm urealnia nasze życie moralne. Etyka kosmopolityczna, wymagająca od nas zaangażowania na rzecz ludzi, których nie znamy, przemienia życie moralne w fikcję. Nie jesteśmy w stanie objąć uczuciami moralnymi całej ludzkości. Możemy człowieka uczynić istotą bardziej moralną jeśli skierujemy jego uczucia ku konkretnej, ograniczonej w czasie i przestrzeni, wspólnocie. „Chcąc 
narody poprowadzić ku cnocie, sprawmy najprzód, by kochały ojczyznę" - zaleca Rousseau (Rousseau, 1956, s. 305).

W Uwagach o rządzie polskim Rousseau w sposób drobiazgowy przedstawia program reform, w których kluczową rolę miało odegrać patriotyczne wychowanie. Przykład Polaków nastrajał go optymistycznie; pokazuje, że wśród narodów nowożytnych przetrwał taki, który zachował cechy ludów starożytnych. Polakom udało się zachować miłość do ojczyzny.

Udaje mu się wydobyć z mitologii konfederatów - pisze Bronisław Baczko - zaczątek ideologii narodowej, podobnie jak uznaje w narodowej wyjątkowości i związanych z nią wartościach siłę napędowa, którą może wykorzystać „prawdziwy polityk", przesuwający "granice możliwości" (Baczko, 2016, s. 95).

Okazuje się, że

prawdziwym sensem polityki nie jest sztuka rządzenia ludźmi, lecz sztuka uszlachetniania serc i dusz, a wielkość prawdziwego polityka objawia się $\mathrm{w}$ ustanowionym przezeń systemie oświaty publicznej (Baczko, 2016, s. 100).

Podsumujmy krótko - myśliciele Oświecenia, mimo różnic, wierzyli, że człowieka można udoskonalić. Mogło to się dokonać dzięki reformie praw, instytucji, wychowania, rozwojowi wiedzy, rozwojowi handlu, wolnej dyskusji czy patriotyzmowi.

Od czasu sformułowania tych obietnic byliśmy świadkami reform politycznych w duchu Oświecenia, bezprecedensowego rozwoju wiedzy naukowej, rozwoju wolnego handlu, wolności dyskusji i rozwoju edukacji. Dwa stulecia od czasu śmierci Rousseau to także okres rozkwitu nacjonalizmów. Czy można powiedzieć, że w tym okresie spełniły się nadzieje myślicieli Oświecenia? Spróbujmy odpowiedzieć na to pytanie, przywołując głosy sceptyków.

\section{SPOŁECZEŃSTWO MASOWE}

Dojście do głosu demokratycznych żywiołów w czasie rewolucji francuskiej przeraziło wielu obserwatorów. Niektórzy sądzili, że można powrócić jeszcze do dawnych form ustrojowych i panujących form 
legitymizacji, inni nie mieli takich złudzeń. Do tych ostatnich należał Alexis de Tocqueville, który sądził, że „wielkiej rewolucji demokratycznej” nie można powstrzymać. Nie ma powrotu do społeczeństwa arystokratycznego. Demokracja zwycięża, ale wbrew temu, co mogli o tym myśleć jej zwolennicy, dla Tocqueville’a nie był to powód do optymizmu. Obraz triumfującej demokracji, który nam przedstawił, nie jest tożsamy ani z katastrofizmem niektórych konserwatystów, ani z entuzjazmem demokratów. Demokracja może przybrać różne kształty - można ją ukształtować (aczkolwiek nie jest to proste) tak, aby szanowała ludzką wolność. Może jednak przybrać formy antypatyczne. Obecnie przywykliśmy do tego, że przeciwstawiamy demokrację różnym formom tyranii czy despotyzmu. Samo słowo jest otoczone szacunkiem. Wyjaśnienie tego fenomenu znajdziemy u Tocqueville'a. Jako pierwszy zwrócił uwagę na to, że w tym ustroju rozpowszechnia się zwyczaj schlebiania ludowi. Uważał on, że demokracja nie wyklucza tyranii czy despotyzmu, więcej - wywołuje zagrożenie stworzenia jej nowego typu. Obawiał się, że demokrację „pozostawiono (...) jej dzikim instynktom. Wzrosła jak dzieci pozbawione opieki rodzicielskiej, które wychowują się same na ulicach naszych miast, mając do czynienia tylko z nędzą i występkiem". Przyjęto władzę ludu w tej prymitywnej postaci - „Uwielbiono ją jako bożka siły" (Tocqueville, 1996, s. 9).

Za cechę człowieka demokratycznego uznał Tocqueville indywidualizm. Inaczej niż obecnie, nie używał tego pojęcia w znaczeniu pozytywnym. Indywidualizm powstaje $\mathrm{w}$ wyniku rozpadu więzi społecznych. Rozpad hierarchicznych zależności typowych dla społeczeństwa arystokratycznego prowadzi do osamotnienia jednostki. $Z$ jednej strony jednostka jest wolna $w$ tym znaczeniu, że nie jest zależna. Z drugiej jednak strony to odosobnienie sprawia, że czuje się bezradna, przeświadczona o niezdolności do kształtowania spraw publicznych.

Relację między władzą demokratyczną a jednostką porównuje Tocqueville do relacji rodzice - dzieci. Przypomina ona władzę ojcowska, z tą istotną różnica, że celem władzy ojcowskiej jest doprowadzenie dzieci do dorosłości. Władza demokratyczna natomiast utrzymuje jednostki w stanie niedojrzałości. Jeśli porównamy to z Kantowskim określeniem Oświecenia jako „wyjścia ze stanu niepełnoletniości", to okazuje się, że demokracja nie tylko nie sprzyja 
emancypacji jednostki, ale sama traktuje jednostki jak dzieci. A zatem człowiek demokratyczny nie jest istotą zdolną do pokierowania odpowiedzialnie sprawami publicznymi.

Ten sposób mówienia o społeczeństwie nie stał się tylko udziałem wrogich wobec Oświecenia i nowoczesnych procesów emancypacyjnych konserwatystów. José Ortega y Gasset sądził, że liberalna demokracja jest wielkim osiągnięciem cywilizacyjnym, ponieważ zastąpiła przemoc dyskusją i przyznaje prawo istnienia przeciwnikowi, nawet jeśli jest słabszy. To jednak on bodaj w największym stopniu przyczynił się do popularyzacji idei społeczeństwa masowego i przemiany obrazu demosu w obraz groźnej, niszczącej dorobek cywilizacyjny, masy. W Buncie mas Ortega y Gasset twierdził, że cywilizacja europejska znalazła się w okresie najcięższego w swej historii kryzysu. Bunt człowieka masowego to bunt ludzi przeciętnych, którzy nie chcą już słuchać lepszych od siebie. Mimo że jednym z przykładów takiego buntu w sferze politycznej była dla Ortegi y Gasseta rewolucja rosyjska, to nie należy jego stanowiska zbywać jako arystokratycznej pozy. Masą nie są ludzie biedni, wyróżnikiem są cechy charakteru, a nie pozycja materialna czy zawodowa.

Ortega y Gasset nazywa człowieka masowego barbarzyńcą. Barbarzyńcę cechuje radykalny brak poczucia wdzięczności i poczucie nieograniczonych możliwości. Świat wyrafinowanej cywilizacji, w której się wychował, traktuje jako coś danego, jak powietrze, którym oddycha. Brakuje mu poczucie tragizmu życia, „wypełnia go poczucie panowania i triumfu" (Ortega y Gasset, 2016, s. 112).

Człowiek masowy nie rozumie idei kultury, w którą wbudowana jest idea samoograniczenia i trudu. Uważa, że życie oddane przyjemnościom po prostu mu się należy. Człowiek należący do elity, pewnego rodzaju naturalnej arystokracji, żyje według maksymy, że szlachectwo zobowiązuje i stawia przed sobą wymagania. Żywi przekonanie o własnej niedoskonałości i kieruje się poczuciem obowiązku, aby się doskonalić. W odróżnieniu od niego człowieka masowego cechuje "hermetyzm duszy”, uważa siebie za doskonałego i nie stawia wobec siebie wymagań.

W życiu człowieka masowego nie ma miejsca na myślenie. To co nazywa własnymi myślami, to „zbiór komunałów”, ,szczątków idei”, , "przesądów” czy „pustych słów”, , "które za sprawą przypadku nagromadził we własnym wnętrzu" (Ortega y Gasset, 2016, s. 79). 
Prawda w życiu człowieka masowego nie jest ideą regulatywną. Jego głowa jest wypełniona "gotowymi myślami”. Jego idee to „pragnienia ujęte w słowa". Człowieka masowego cechuje także brak zdolności do słuchania (Ortega y Gasset, 2016, s. 83).

Tocqueville uważał, że jest rzeczą otwartą, czy demokracja przybierze kształt nowej tyranii, Ortega y Gasset również nie tracił nadziei, ale wymowa ich wywodów skłania czytelnika do pesymizmu.

\section{PARADOKS WSPÓŁCZESNEJ DEMOKRACJI}

Doświadczenie dwudziestowiecznych totalitaryzmów w jeszcze większym stopniu zachwiały wiarę w człowieka. Jan Werner Müller w książce o populizmie stawia pytanie: Czy można ufać narodom, które wyniosły do władzy faszystów? (Müller, 2017). Patriotyzm, który Rousseau przedstawiał jako postawę, dzięki której człowieka można udoskonalić moralnie, traktowany jest przez wielu intelektualistów z największą podejrzliwością.

We współczesnej demokracji widoczny jest lęk przed ludem. Przyczynił się do tego w dużej mierze liberalizm. Judith Shklar w swoich studiach nad liberalizmem zwraca uwagę na mizantropię twórców liberalizmu. Monteskiusz „sądził, że źli ludzie, a za takich miał Anglików, mogą stworzyć najlepsze instytucje i być najbardziej wolnymi i sprawiedliwymi obywatelami” (Shklar, 1997, s. 225). Ustrój zależy od mechanizmów i praw, a nie ludzkich cnót. „Rządzić mają procedury, a nie ludzie. Żadna cnota nie ma znaczenia z wyjątkiem sprawiedliwości, a sprawiedliwość nie jest związana z uczuciem" (Shklar, 1997, s. 225). Na tym polega sztuka polityczna. „Zdepersonalizowany charakter państwa prawa - pisała Shklar - był od dawna uważany za dowód jego racjonalności. Była to wyspa rozumu na morzu ludzkiej irracjonalności. W ten sposób podstawową cechą systemu nie były ani występki, ani cnoty" (Shklar, 1997, s. 226).

Ta nieufność wobec społeczeństwa znajduje swój wyraz w dążeniu do ograniczenia uprawnień organów wybieranych w wyborach powszechnych i przeniesieniu punktu ciężkości w procesie podejmowania decyzji na sądownictwo. To sędziowie - jak to określił Alasdair MacIntyre - są kapłanami współczesnego liberalizmu. Pojęcie „sądokracji” zazwyczaj używane jest przez ludzi, którzy odnoszą się 
do tego procesu krytycznie, ale ma ono także swoich zwolenników. Przywołajmy jeden przykład. Niektórzy przeciwnicy reform ustrojowych, wprowadzonych przez partię Viktora Orbana na Węgrzech, twierdzą że funkcjonujący wcześniej ustrój, w którym główną rolę odgrywało sądownictwo konstytucyjne, lepiej realizował wartości demokratyczne niż obecny, w którym główną rolę odgrywa parlament (Furedi, 2017).

Innym przykładem nieufności wobec ludu jest merytokracja. Skoro uważa się masy za niezdolne do racjonalnej perswazji, ciężar debaty powinny przejać wyspecjalizowane instytucje merytokratyczne.

Kolejnym przejawem strachu jest stosunek do wolności słowa. Mimo formalnych gwarancji dla wolności wypowiedzi, jesteśmy świadkami jej ograniczania. Kryminalizacja „mowy nienawiści”, tworzenie kodów mowy politycznie poprawnej wynikają z przeświadczenia, że ludziom nie powinno się pozwalać na mówienie tego, co myślą w kontrowersyjnych sprawach. Wzrost praktyk cenzorskich wynika z paternalistycznego i negatywnego poglądu na naturę ludzką (Furedi, 2006a, s. 106).

Inna wielka przemiana kulturalna odzwierciedla przeświadczenie, że człowiek jest w większym stopniu obiektem zewnętrznego kształtowania, na które nie ma wpływu, niż sam kształtuje samego siebie. Znalazło to odzwierciedlenie w kulturze ofiar. Tożsamość jednostek i całych grup jest określona przez odległe doświadczenie, od którego nie może się uwolnić. Nie kontrolujemy konsekwencji tego doświadczenia. W Wielkiej Brytanii jest ponad 300 organizacji, które mają słowo „ofiara” w nazwie (Furedi, 2006a, s. 106). Kultura terapeutyczna podważa ideę racjonalnego podmiotu, który świadomie kieruje swoim postępowaniem (Furedi, 2006 c, s. 73).

Demokracja, u której źródeł leżała nadzieja przekształcenia za pomocą polityki ludzkiego życia, stała się ustrojem, w którym bardzo silny jest strach przed ludem. Ustrój ten wprawdzie nosi nazwę demokracja, ale ma niewiele wspólnego z nadziejami, jakie z nim łączyli autorzy, którzy sformułowali jej intelektualne założenia. 


\section{BiBLIOGRAFIA}

Baczko, B. (2016). Światła utopii. Warszawa: Wydawnictwo Instytutu Filozofii i Socjologii PAN.

Cassirer, E. (2010). Filozofia Oświecenia. Warszawa: Wydawnictwa Uniwersytetu Warszawskiego.

Condorcet, A.N. (1957). Szkic obrazu postępu ducha ludzkiego poprzez dzieje. Warszawa: Wydawnictwo Naukowe PWN.

Filipowicz, S. (2007). Demokracja: o władzy iluzji w królestwie rozumu. Warszawa: Wydawnictwa Akademickie i Profesjonalne.

Furedi F (2006a). Culture Of Fear Revisited. London: Continuum.

Furedi, F. (2006b). Politics of Fear. London: Continuum.

Furedi, F. (2017). Populism and the European Culture Wars. London: Routledge.

Furedi, F. (2006c). Where Have All the Intelectuals Gone? Confronting 21st Century Philistinism. London: Continuum.

Furet, F. (1997). Rousseau and the French Revolution. W: C. Orwin, N. Tarcov (ed.), The Legacy of Rousseau. Chicago: The University of Chicago Press.

Hazard, P. (1972). Myśl europejska w XVIII wieku. Od Monteskiusza do Lessinga. Warszawa: Państwowy Instytut Wydawniczy.

Himmelfarb, G. (2018). Drogi do nowoczesności. Brytyjskie, francuskie i amerykańskie Oświecenie. Warszawa: Teologia polityczna.

Kant, I. (2012). Co to jest Oświecenie?. W: S. Filipowicz i in. (red.), Historia idei politycznych. Warszawa: Wydawnictwa Uniwersytetu Warszawskiego.

Madison, J. (1999). Numer 51. W: Eseje polityczne federalistów. Kraków: SIW Znak.

Múller, J.W. (2010). Co to jest populizm? Warszawa: Wydawnictwo Krytyki Politycznej.

Ortega y Gasset, J. (2016). Bunt mas. Warszawa: Wydawnictwo Literackie Muza.

Plattner, M.P. (1997). Rousseau and the Origins of Nationalism. W: C. Orwin, N. Tarcov (ed.), The Legacy of Rousseau. Chicago: The University of Chicago Press.

Rousseau, J.J. (1956). Ekonomia polityczna. W: J.J. Rousseau, Trzy rozprawy z filozofii społecznej. Warszawa: Wydawnictwo Naukowe PWN.

Rousseau, J.J. (2010). Umowa społeczna. W: J.J. Rousseau, Umowa spoteczna. List o widowiskach, Warszawa: Wydawnictwo Naukowe PWN.

Shklar, J. (1997). Zwyczajne przywary. Kraków - Warszawa: SIW Znak.

Smith, A. (1989). Teoria uczuć moralnych. Warszawa: Wydawnictwo Naukowe PWN. 
Tocqueville, A. de (1996). O demokracji w Ameryce, t. 1. Kraków - Warszawa: SIW Znak.

\section{Copyright and License}

This article is published under the terms of the Creative Commons Attribution - NoDerivs (CC BY- ND 4.0) License http://creativecommons.org/licenses/by-nd/4.0/ 